УДК 330.34:339.56(045)

\title{
ІНТЕЛЕКТУАЛІЗАЦІЯ МІЖНАРОДНОЇ ТОРГІВЛІ В УМОВАХ ПАНДЕМІї COVID-19
}

\section{INTELLECTUALIZATION OF INTERNATIONAL TRADE IN THE CONTEXT OF THE COVID-19 PANDEMIC}

\author{
Пічкурова Зоя Володимирівна \\ кандидат економічних наук, доцент, \\ Національний авіаційний університет \\ ORCID: https://orcid.org/0000-0002-6561-8413
}

\author{
Pichkurova Zoia \\ National Aviation University
}

\begin{abstract}
Стаття присвячена ролі інтелектуальної компоненти у розвитку міжнародної торгівлі в умовах пандемії COVID-19. Визначено форми та особливості інтелектуалізації міжнародної торгівлі під впливом карантинних обмежень. Досліджено вплив пандемії COVID-19 на обсяги, структуру і динаміку міжнародної торгівлі та проаналізовано прогнозні дані щодо подальшого розвитку міжнародної торгівлі. Проведено аналіз міжнародної торгівлі телекомунікаційними, комп'ютерними та інформаційними послугами, а також високотехнологічними товарами в умовах пандемії. Досліджено ринок об'єктів інтелектуальної власності в умовах пандемічної кризи. Приділено увагу особливостям розвитку електронної комерції і поглибленню процесів цисровізації торговельних операцій, каталізатором яких стали карантинні обмеження. Зазначено, що незважаючи на деструктивний вплив пандемії COVID-19 на світову економіку, вона стала каталізатором процесів інтелектуалізації міжнародної торгівлі.

Ключові слова: інтелектуалізація, міжнародна торгівля, COVID-19, коронавірус SARS-CoV-2, пандемія, коронавірусна криза, пандемічна криза, інтелектуальний потенціал, інтелектуалізовані товари та послуги, інтелектуальна власність, електронна комерція.
\end{abstract}

Статья посвящена роли интеллектуального компонента в развитии международной торговли в условиях пандемии COVID-19. Определены формы и особенности интеллектуализации международной торговли под влиянием карантинных ограничений. Исследовано влияние пандемии COVID-19 на объемы, структуру и динамику международной торговли и проанализированы прогнозные данные по дальнейшему развитию международной торговли. Проанализирована международная торговля телекоммуникационными, компьютерными и информационными услугами, а также высокотехнологичные товары в условиях пандемии. Исследован рынок объектов интеллектуальной собственности в условиях пандемического кризиса. Автором уделено внимание особенностям развития электронной коммерции и углублению процессов цифровизации торговых операций, катализатором которых стали карантинные ограничения. Отмечено, что, несмотря на деструктивное влияние пандемии COVID-19 на мировую экономику, она стала катализатором процессов интеллектуализации международной торговли.

Ключевые слова: интеллектуализация, международная торговля, COVID-19, коронавирус SARS-CoV-2, пандемия, коронавирусный кризис, пандемический кризис, интеллектуальный потенциал, интеллектуализированные товары и услуги, интеллектуальная собственность, электронная коммерция.

The article is devoted to the role of the intellectual component in the development of international trade in the context of the COVID-19 pandemic. The forms and features of intellectualization of international trade under the influence of quarantine restrictions are determined. The impact of the COVID-19 pandemic on the volume, structure and dynamics of international trade has been studied and forecast data on the further development of international trade have been analyzed. The areas most affected by the coronavirus crisis and the areas that managed to achieve growth were identified. Special attention is paid to the analysis of international trade in telecommunications, computer and information services, as well as high-tech goods in a pandemic. The market of intellectual property objects and its impact on the economic development of countries in the pandemic crisis is analyzed and the tendency of reduction of revenues from the use of intellectual property in favor of major world exporters is determined. At the same time, the dynamics of intellectual property imports was studied and the trend of increasing revenues from key importers of intellectual property was determined. It was emphasized that the sphere of intellectual property demonstrates 
resilience to the consequences of the COVID-19 pandemic, as evidenced by the growing number of applications for registration of intellectual property (patents, trademarks, industrial designs, plant varieties). It is determined that the intensification of inventive activity indicates an increase in demand for intellectual property in the world market and provides an opportunity to talk about their role as drivers of economic growth against the background of the general recession. The author pays attention to the development of e-commerce and the deepening of the processes of digitalization of trade operations, the catalyst of which were quarantine restrictions. It is noted that despite the destructive impact of the COWID-19 pandemic on the world economy, it has become a catalyst for the intellectualization of international trade and proved the effectiveness of the strategy of focusing on intellectual potential.

Keywords: intellectualization, international trade, COVID-19, coronavirus SARS-CoV-2, pandemic, coronavirus crisis, pandemic crisis, intellectual potential, intellectualized goods and services, intellectual property, e-commerce.

Постановка проблеми. Процеси інтелектуалізації глобальної економіки, які набувають вирішального значення для її подальшого розвитку, генерують зміни у орормах міжнародних економічних відносин, насамперед, у міжнародній торгівлі та сприяють виникненню нових фоорм і методів конкуренції на світовому ринку. Водночас, пандемія COVID19 внесла серйозні корективи у тенденції розвитку міжнародної торгівлі і довела значення інтелектуального потенціалу як визначального фрактору конкурентоспроможності країнучасниць глобальної торговельної системи. Сьогодні суб'єкти міжнародної торгівлі у відповідь на пандемічні виклики шукають можливості для створення і впровадження інноваційних інструментів взаємодії зі споживачами та пропонують нові продукти і послуги, які $€$ конкурентоспроможними, але, водночас, не суперечать карантинним обмеженням. Коронавірусна криза фрактично стала індикатором економічної стійкості суб'єктів міжнародної торгівлі та каталізатором їі якісної трансорормації шляхом інтелектуалізації.

Аналіз останніх досліджень і публікацій. Інтелектуалізація як характерна ознака розвитку сучасної глобальної економіки є предметом дослідження вітчизняних та зарубіжних учених, таких, як М. Ажажа, Ю. Бажал, Д. Белл, Е. Брукинг, В. Геєць, Дж. Гелбрейт, П. Друкер, Л. Едвінссон, В. Іноземцев, П. Крайнєв, Д. Лук'яненко, М. Поляков, Д. Попова, А. Самойленко, С. Сардак, Т. Стюарт, Л. Федулова, Є. Фоміна, Т. Шульц та інші. Питанням актуалізації інтелектуальної компоненти у міжнародній торгівлі приділяли увагу такі вітчизняні та зарубіжні дослідники, як Л. Войтова, Д. Давидов, Г. Геворкян, Ю. Піскулов, А. Спартак, Т. Циганкова, П. Цвіленберг, О. Яценко та інші.

Виділення невирішених раніше частин загальної проблеми. Незважаючи на значну увагу з боку вітчизняних та зарубіжних учених до проблематики інтелектуалізації глобального економічного розвитку, трансфор- мація міжнародної торгівлі в умовах пандемії COVID-19, форми і особливості її інтелектуалізації залишається недостатньо вивченими, але надзвичайно актуальними 3 огляду на вплив інтелектуалізованих продуктів і послуг не лише на розвиток торговельного потенціалу країн, але й на їх економічну стійкість в умовах невизначеності і кризи.

Формулювання цілей статті. Метою даного дослідження $є$ аналіз особливостей і тенденцій інтелектуалізації міжнародної торгівлі в умовах пандемії COVID-19.

Виклад основного матеріалу дослідження. Однією із характерних ознак розвитку сучасної світової економіки є посилення впливу на неї інноваційних фракторів та зростання значення інтелектуального капіталу. Науково-технічний прогрес породжує зміни і у структурі міжнародної торгівлі, що проявляються, насамперед, через зменшення частки сировинних товарів та зростання частки товарів і послуг, що містять інтелектуальну компоненту, цінність і попит на які стрімко зростає.

Водночас, пандемія, викликана коронавірусом SARS-CoV-2 продемонструвала свій вагомий вплив на структуру, обсяги, темпи зростання міжнародної торгівлі та кардинально змінила ситуацію на світових ринках. Основними проблемами, які відчули на собі світові товаровиробники під час пандемії, $€$ : закриття виробництв, зростання вартості робочої сили, виникнення необхідності скорочення ланок у мультинаціональних ланцюгах постачання тощо. Пандемія COVID-19 стала каталізатором процесів створення нових продуктів та послуг, які дозволяють учасникам світового ринку зберегти економічну стійкість та задовольнити вимоги споживачів в умовах карантинних обмежень.

За даними дослідницької та консалтингової компанії Gartner, світова торгівля новими продуктами та послугами, створеними за період пандемії, забезпечить у світових масштабах до 30 млрд. дол. США доходів до 2023 р. [1]. Крім цього, до 2024 р. у міжнародній торгівлі 
остаточно сфрормується «пандемічна» тенденція, відповідно до якої виробники товарів і послуг, які орункціонують у нетехнологічній сорері, у відповідь на стрімке зростання технологічних запитів споживачів перетворяться на самостійних виробників новітніх технологічних товарів та послуг, внаслідок чого стануть прямими конкурентами традиційним виробникам технологій. Дана тенденція спостерігається вже зараз і найбільш виразно проявляється у сорері фрінансових послуг та ритейлу.

За даними Світової організації торгівлі (СОТ), у 2020 р. обсяги світової торгівлі товарами знизились на $8 \%$ після дворічного зростання. Світова торгівля товарами та послугами у 2020 р. склала 22 трлн. дол. США, що на $12 \%$ менше, ніж у 2019 р. Обсяг світового експорту товарів склав 17,6 трлн. дол. США, що на 1,4 трлн. дол. США менше, ніж у попередньому році. Конореренція ООН з торгівлі та розвитку (ЮНКТАД) прогнозує зростання обсягів світового експорту товарів у 2021 р. на 22,4\% незважаючи на пандемічні виклики [2].

3 огляду на низькій рівень стійкості міжнародної торгівлі деякими видами послуг до карантинних обмежень, у 2020 р. світовий експорт послуг скоротився на $21 \%$ і його обсяг становив 5 трлн. дол. США. За прогнозом ЮНКТАД, у 2021 році очікується зростання даного показника на 13,6\% порівняно 32020 р. [2]. Під час пандемії зберіглась тенденція переважання міжнародної торгівлі послугами над міжнародною торгівлею товарами, що спостерігалась протягом останніх років: у 2020 р. частка послуг у загальному обсязі світової торгівлі склала $77 \%$. Можна припустити, що у найближчі роки лідерські позиції у світовій торгівлі також будуть належати виробникам послуг.

Зниження обсягів світової торгівлі товарами у 2020 р. під час пандемії COVID-19 було викликано переважно зниженням цін на паливо, експорт якого скоротився на 33,1\%. Крім цього, на 5,7\% скоротився експорт сільськогосподарської сировини та на 4,4\% - експорт промислової продукції. Експорт руд, металів, дорогоцінного каміння та немонетарного золота зріс на 5,7\%, а торгівля продуктами харчування майже на 1,6\% (див. рис. 1).

Під впливом пандемії COVID-19 зменшились обсяги світової торгівлі основними видами послуг. Найвищі темпи скорочення були зафріксовані у сорері туризму (-62,6\%), транспортних послуг (-20,3\%). Водночас, серед основних категорій послуг телекомунікаційні, комп'ютерні та інфрормаційні послуги виявились єдиною групою, яка продемонструвала зростання на 4,1\% у 2020 р. Експорт страхових, фрінансових послуг, послуг у сорері інтелектуальної власності та інших бізнес-послуг виявився максимально стійким до пандемічного впливу і скоротився лише на 3,1\% (див. рис. 1). Лідерські позиції за обсягами експорту даної групи послуг належать країнам з розвиненою економікою, які за підсумками 2020 р. охопили 70,8\% даного ринку.

За обсягами експорту телекомунікаційних, комп'ютерних та інформаційних послуг у 2020 р. першість у світі належить Європейському регіону, який охоплює 55,6\% даного ринку, друге місце - Азії (26,2\%), третє - Північній Америці (9,4\% ринку). Серед досліджуваних регіонів у 2020 р., попри пандемічну кризу, свої позиції зміцнили Азія (на 0,8\%) та Близький Схід (на 0,4\%) (див. рис. 2).

Хоча пандемія COVID-19 негативно вплинула на сфреру високих технологій, динаміка світової торгівлі високотехнологічними товарами у 2020 р. була позитивною у порівнянні 3 іншими товарними групами. Це пов'язано зі зростанням попиту на комунікаційне обладнання, електронно-обчислювальну техніку, технології обробки і зберігання даних у зв'язку із переходом працівників та учасників освітньої діяльності у всьому світі на дистанційний формат роботи. Зважаючи на значну популяризацію віддаленої роботи, останнім часом особливо актуальним стає питання технічного оснащення «домашніх офрісів», у зв'язку з чим зростає попит на технічні засоби, якими необхідно забезпечити персонал. Отже, основною причиною відносної стійкості високотехнологічних товарів до пандемічної кризи є трансформація поведінки споживачів.

За даними Світового банку, частка світового експорту високотехнологічних товарів у загальному обсязі експорту товарів у 2020 р. перевищила показник 2019 року на 1,5\% і склала $22 \%$. До трійки лідерів за даним показником у 2020 р. увійшли Гонконг (70\%), Філіппіни (64\%) та Сінгапур (55\%). Щодо країн $€ C$, то у 2020 р. частка високотехнологічної продукції становила 16\% загального експорту $\in C$, що на 0,1\% менше, ніж у 2019 р., а обсяг реалізованої високотехнологічної продукції склав 644,3 млрд. дол. США і знизився на $7 \%$ порівняно з 2019 р.

Реакцією ринку об'єктів інтелектуальної власності на пандемію стала тенденція скорочення обсягів доходів основних світових експортерів від реалізації об'єктів інтелектуальної власності. Як видно з рис. 3, серед 


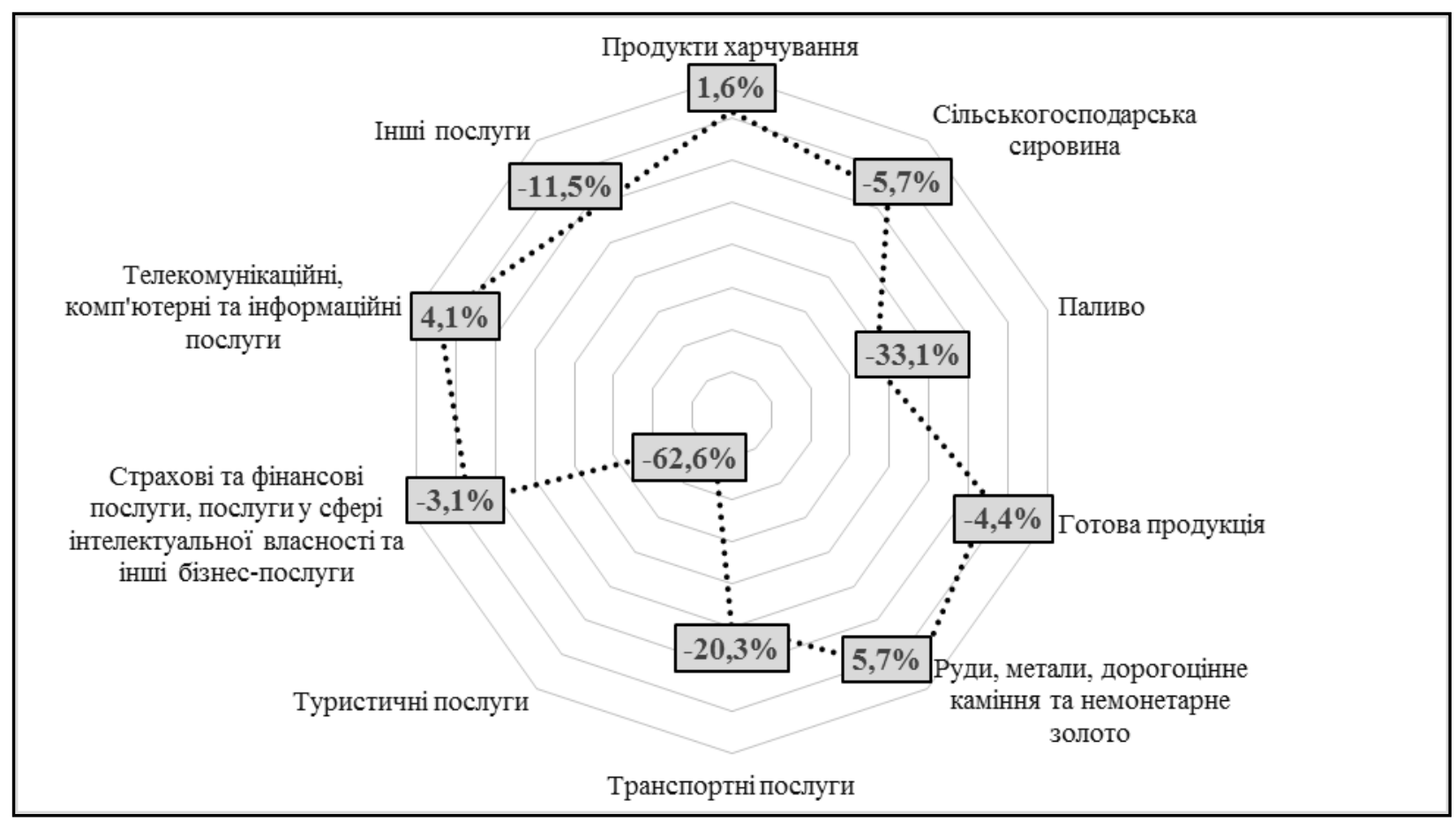

Рис. 1. Динаміка світового експорту товарів та послуг у 2020 р., \% Джерело: побудовано автором за даними ЮНКТАД [2]

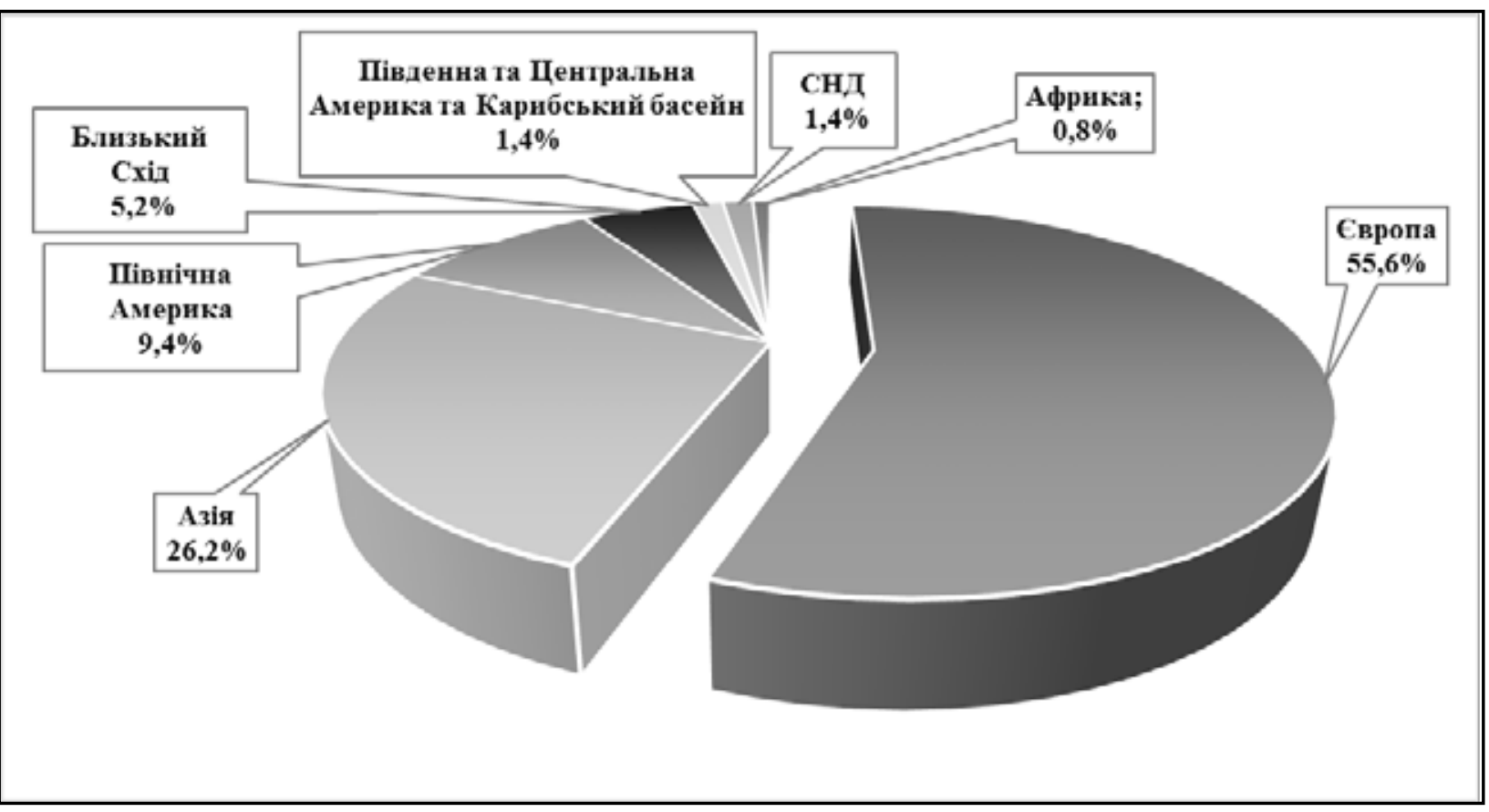

Рис. 2. Обсяги світового експорту телекомунікаційних, комп'ютерних та інформаційних послуг за регіонами світу у 2020 році, \%

Джерело: побудовано автором за даними Світової організації торгівлі [3]

ключових експортерів зниження обсягів таких надходжень у 2020 р. у порівнянні 32019 р. найбільш відчутним було у Швейцарії (-23\%), Об'єднаних Арабських Еміратах (-21\%), Європейському Союзі (-14\%), Республіці Кореї
(-12\%) тощо. Водночас, Китаю вдалося забезпечити приріст обсягів доходів від інтелектуальної власності на рекордні $34 \%$. Дану тенденцію можна пояснити тим, що Китай першим розпочав боротьбу із наслідками COVID-19, 


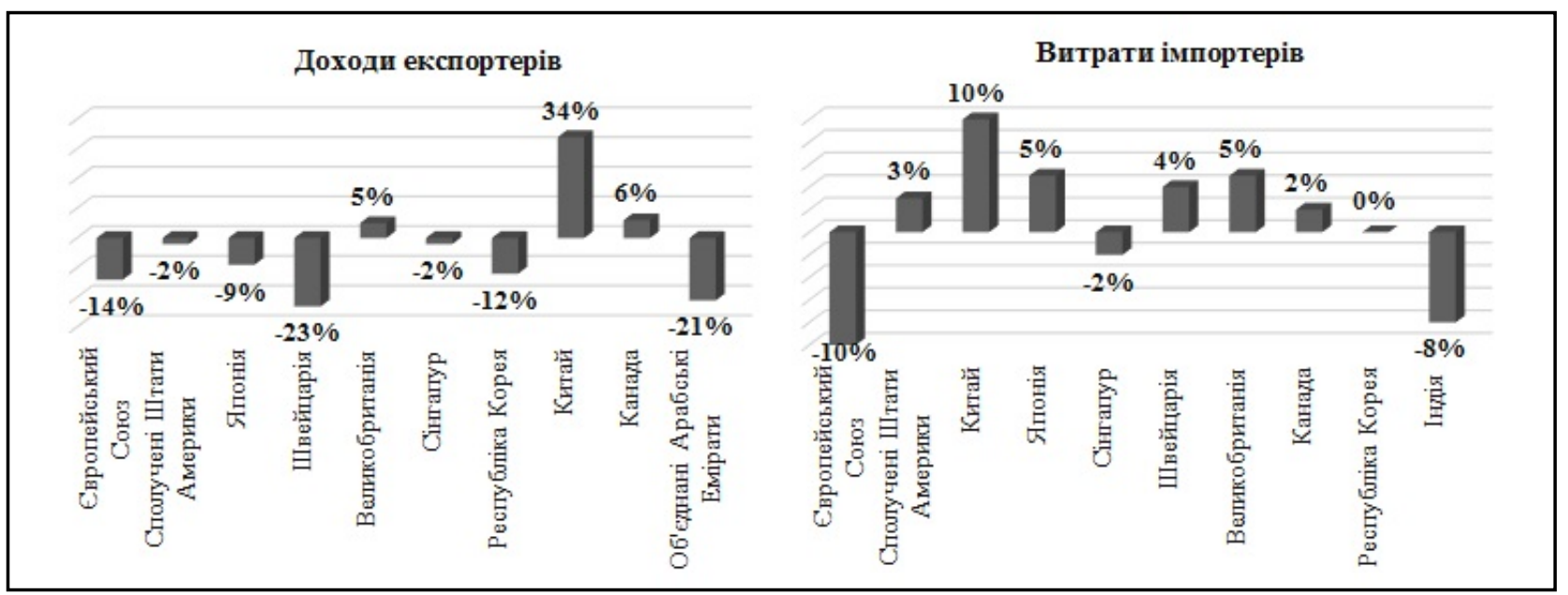

Рис. 3. Динаміка обсягів доходів та витрат від експортно-імпортних операцій з реалізації об'єктів інтелектуальної власності у 2020 р., \%

Джерело: побудовано автором за даними Світової організації торгівлі [3]

зокрема, шляхом розробки і впровадження новітніх технологічних рішень, передусім, у сорері медицини та електронної комерції, які виявились конкурентоспроможними на світовому ринку. Це дозволило Китаю не лише подолати наслідки пандемії, але й збільшити обсяги експорту високотехнологічних товарів.

Варто зазначити, що навіть в умовах пандемії більшості провідних імпортерів світу вдалося підвищити темпи торгівлі об'єктами інтелектуальної власності, про що свідчать статистичні дані, наведені на рис. 3. Так, обсяги виплат за використання інтелектуальної власності у 2020 р. проти 2019 р. зросли на 10\% у Китаї, на $5 \%$ у Японії та на $5 \%$ у Великобританії, на 4\% у Швейцарії, на 3\% у США та на 2\% у Канаді. Зниження даного показника у 2020 р. серед обраної для дослідження групи країн спостерігалося в Європейському Союзі (-10\%), Індії (-8\%) та Сінгапурі (-2\%).

3 метою аналізу процесів інтелектуалізації міжнародної торгівлі доцільним є дослідження тенденцій розвитку сфери інтелектуальної власності у період пандемії, викликаної коронавірусом SARS-CoV-2. У 2020 р., незважаючи на глобальну економічну кризу, сорера інтелектуальної власності продемонструвала позитивну динаміку, що свідчить про активізацію підприємницької діяльності у сорері інновацій та створення нових товарів і послуг, які стали актуальними та конкурентоспроможними під час коронавірусної пандемії. Передусім, це стосується технологій, що дозволяють забезпечити дотримання карантинних норм, медичних технологій, фрармацевтичних препаратів та біотехнологій.
Зазначена тенденція демонструє стійкість сорери інтелектуальної власності до наслідків пандемії COVID-19 порівняно 3 періодом глобальної фрінансової кризи 2008-2009 рр., за якої відбулося суттєве скорочення кількості заявок на реєстрацію основних об'єктів інтелектуальної власності (патентів, торговельних марок, промислових зразків, сортів рослин) (див. рис. 4). Окрім цього, протягом 2020 р. світовій патентній системі вдалося не лише наздогнати показники докарантинного періоду, але й перевищити їх. Так, у 2020 р. кількість патентних заявок зросла на 1,6\%, заявок на реєстрацію торговельних марок на 13,7\%, промислових зразків - на 2\%, сортів рослин - на 5,1\% (див. рис. 4). Така активізація винахідницької діяльності свідчить про зростання попиту на об'єкти інтелектуальної власності на світовому ринку і дає можливість стверджувати про їх роль як драйверів економічного зростання на фоні загальної рецесії.

Слід додати, що незважаючи на глобальну кризу, протягом 2020 р. поряд зі збільшенням кількості заявок на реєстрацію об'єктів інтелектуальної власності у світі спостерігалося зростання обсягів витрат на дослідження і розробки. За попередніми даними, які були оприлюднені у Звіті про Глобальний інноваційний індекс 2021 р., обсяг світових державних витрат на дослідження і розробки у країнах, які є лідерами за даним показником, у 2020 р. продовжував зростати. 60\% наукомістких фрірм світу, що є лідерами за обсягом витрат на дослідження і розробки повідомили про зростання даного показника приблизно на 10\%. Компанії, інноваційні розробки яких 


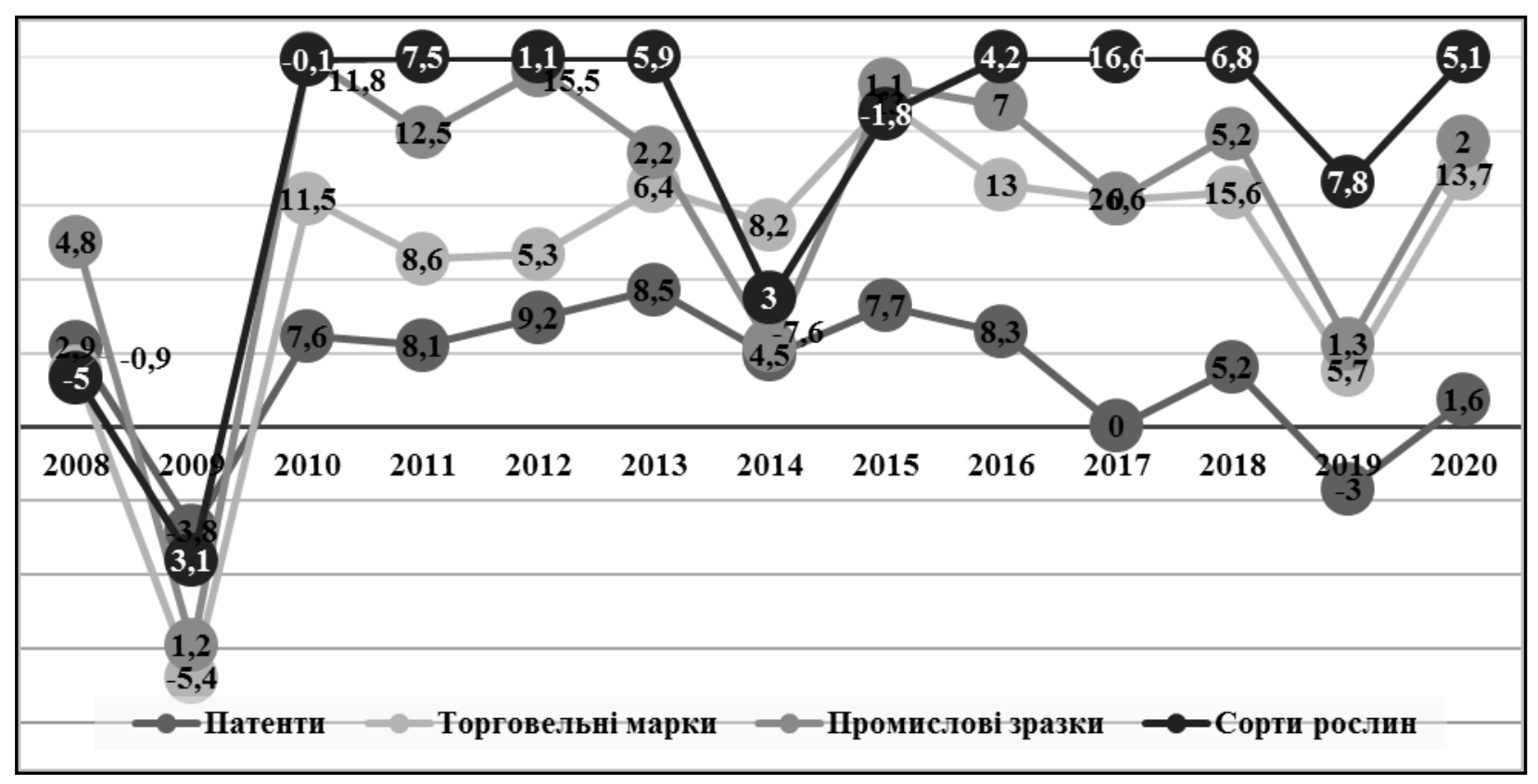

Рис. 4. Динаміка кількості заявок на реєстрацію об'єктів інтелектуальної власності у світі у 2008-2020 рр., (\%)

Джерело: побудовано автором за даними Всесвітньої організації інтелектуальної власності [4]

спрямовані на стримування і подолання пандемії та її наслідків, зокрема у сорері програмного забезпечення, інфрормаційно-комунікаційних технологій, апаратного та електричного обладнання, фрармацевтичних препаратів та біотехнологій збільшили обсяг інвестицій в інновації. Натомість, орірми, які працюють в секторах, що суттєво постраждали від карантинних обмежень, зокрема транспорт і туризм, скорочують свої інноваційні витрати [5].

Однією 3 ознак інтелектуалізації світової торгівлі $€$ прискорений розвиток електронної комерції і поглиблення процесів цисрровізації торговельних операцій, каталізатором яких стали карантинні обмеження. Варто зазначити, що електронна комерція, виходячи з ії беззаперечних економічних переваг, розвивалася стрімкими темпами ще до початку пандемії, але суттєве зростання ії обсягів спостерігається саме у період пандемічної кризи (див. рис. 5).

За даними компанії Statista, яка працює у галузі маркетингових досліджень та статистики, у 2020 р. більше двох мільярдів споживачів у всьому світі купували товари або послуги в мережі Інтернет, а роздрібні продажі в електронній мережі перевищили 4,2 трлн. дол. США [6]. Прогнозується, що темпи зростання електронної комерції не знизяться навіть після повного скасування усіх карантинних обмежень, зокрема, частка електронної комерції у загальному обсязі роздрібних продажів до 2024 р. сягне 21,8\%. Зростання обсягів електронної комерції також супроводжується процесами цифрровізації фрінансового обслуговування міжнародних комерційних операцій, в тому числі із використанням криптовалют.

Кількість цифрових покупців протягом кризового 2020 р. зросла до 2,05 млрд. осіб проти 1,92 млрд. осіб у 2019 р. Порівняння даного показника із показником 2015 р. (1,46 млрд. осіб) свідчить про те, що відбулось зростання майже у 1,5 рази. Очікується, що у 2021 р. понад 2,14 млрд. людей у всьому світі будуть купувати товари та послуги у режимі онлайн. Крім цього, враховуючи те, що учасники міжнародної торгівлі вже набули досвіду щодо дистанційної взаємодії зі споживачами та клієнтами, можна спрогнозувати, що після завершення пандемії їх значна частина може остаточно перейти в онлайн-режим.

Висновки. Незважаючи на деструктивний вплив пандемії COVID-19 на світову економіку, вона стала каталізатором процесів інтелектуалізації міжнародної торгівлі та виступила черговим аргументом на користь ефективності стратегії орієнтації на інтелектуальний потенціал. Як результат, за період карантинних обмежень у світовому торговельному обороті зросла частка інтелектуалізованих товарів та послуг, за рахунок чого окремим суб'єктам міжнародної торгівлі вдалося не 


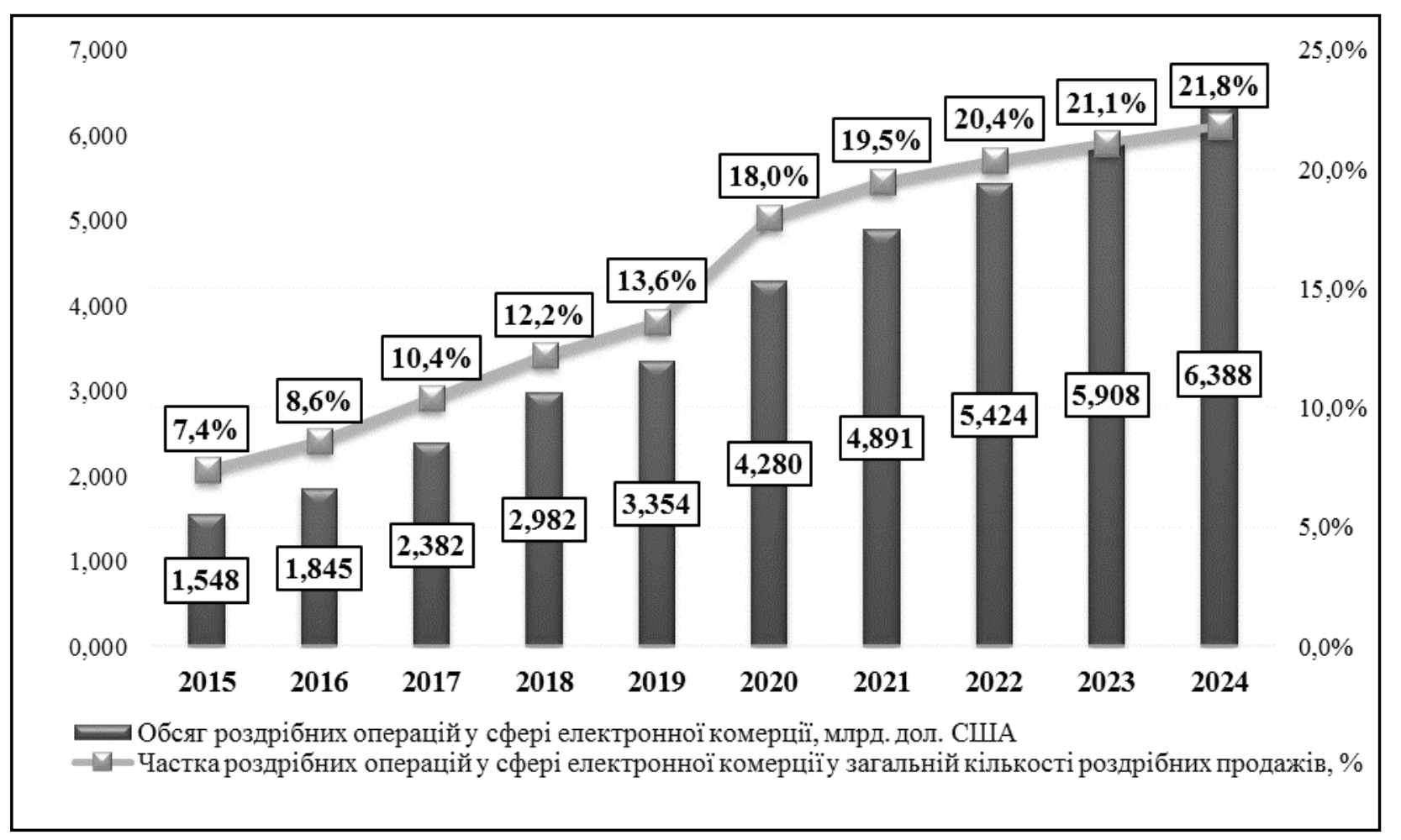

Рис. 5. Динаміка обсягів роздрібних продажів у сфері електронної комерції у світі за період з 2014 по 2020 рр.; 2021-2024 - прогнозні дані, \%

Джерело: побудовано автором за даними компанії Statista [6]

лише зберегти свої позиції на світовому ринку, але й досягти недосяжного у попередні роки рівня доходів. Разом з тим, інтелектуалізація міжнародної торгівлі характеризується ознаками неоднорідності не лише на рівні окремих регіонів та країн, але й на рівні компаній, в результаті чого виникає проблема асиметрії технологічного розвитку. Цілком закономірним є те, що вихід суб'єктів світового ринку на лідерські позиції обумовлений їх ставленням до інтелектуальних ресурсів, готовністю до сприйняття інновацій та здатністю до реалізації міжнародної торговельної діяльності 3 орієнтацію на інноваційний потенціал.

\section{СПИСОК ВИКОРИСТАНИХ ДЖЕРЕЛ:}

1. Gartner Says the Majority of Technology Products and Services Will Be Built by Professionals Outside of IT by 2024. Gartner : веб-сайт. URL: https://www.gartner.com/en/newsroom/press-releases/2021-06-10-gartner-saysthe-majority-of-technology-products-and-services-will-be-built-by-professionals-outside-of-it-by-2024 (дата звернення: 20.12.2021).

2. The UNCTAD Handbook of Statistics 2021. Конфреренція ООН з торгівлі та розвитку : веб-сайт. URL: https://unctad.org/system/files/official-document/tdstat46_en.pdf (дата звернення: 20.12.2021).

3. World Trade Statistical Review 2021. Світова організація торгівлі : веб-сайт. URL: https://www.wto.org/ english/res_e/statis_e/wts2021_e/wts2021_e.pdf (дата звернення: 20.12.2021).

4. World Intellectual Property Indicators. Всесвітня організація інтелектуальної власності : веб-сайт. URL: https://www.wipo.int/publications/en/series/index.jsp?id=37 (дата звернення: 20.12.2021).

5. Global Innovation Index 2021. Всесвітня організація інтелектуальної власності : веб-сайт. URL: https://www.wipo.int/edocs/pubdocs/en/wipo_pub_gii_2021.pdf (дата звернення: 20.12.2021).

6. E-commerce worldwide - statistics \& facts. Statista : веб-сайт. URL: https://www.statista.com/topics/871/ online-shopping/\#dossierKeyfigures (дата звернення: 20.12.2021). 


\section{REFERENCES:}

1. Gartner Says the Majority of Technology Products and Services Will Be Built by Professionals Outside of IT by 2024. Gartner. Available at: https://www.gartner.com/en/newsroom/press-releases/2021-06-10-gartnersays-the-majority-of-technology-products-and-services-will-be-built-by-professionals-outside-of-it-by-2024(accessed 20 December 2021).

2. The UNCTAD Handbook of Statistics 2021. United Nations Conference on Trade and Development. Available at: https://unctad.org/system/files/official-document/tdstat46_en.pdf (accessed 20 December 2021).

3. World Trade Statistical Review 2021. World Trade Organization. Available at: https://www.wto.org/english/ res_e/statis_e/wts2021_e/wts2021_e.pdf (accessed 20 December 2021).

4. World Intellectual Property Indicators. World Intellectual Property Organization. Available at: https://www.wipo.int/publications/en/series/index.jsp?id=37 (accessed 20 December 2021).

5. Global Innovation Index 2021. World Intellectual Property Organization. Available at: https://www.wipo.int/ edocs/pubdocs/en/wipo_pub_gii_2021.pdf (accessed 20 December 2021).

6. E-commerce worldwide - statistics \& facts. Statista. Available at: https://www.statista.com/topics/871/ online-shopping/\#dossierKeyfigures (accessed 20 December 2021). 